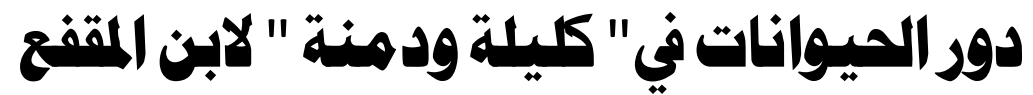

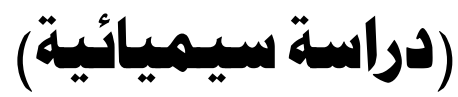

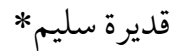

\author{
Abstract \\ The Role of Animals in kalīlät wa dimnä̈ \\ (The Study of Semiotic and Seminal Values)
}

\begin{abstract}
Qadeera Saleem*
This piece of research brings animals characters used in the book titled kalīlä̈ wa dimnä̈ by ibn al-muqfa' under a microscopic view, to see how and what they are saying. The book is undoubtedly one of the stroke of genius of Arab literature. The animals in this book are talking selves who speak in all areas of life, politics, morals, and friendship. It is a collection of allegorical stories by animals that fall within the art of fabrication; it is a fine literature on its own.

He takes the approach of wisdom, setting examples for lessons and education, which the writer adopts for amusement, ridicule or humiliation in a manner that is carried out by animals for fear of the unjust ruler, where animals exploit resourcefulness to achieve their ends, the wise men also formulate tricks in order to carry out their educational role, and their greatest influence on souls is to put proverbs on the tongues of animals.
\end{abstract}

Keywords: kalīlä̈ wa dimnä̈, Stories, Animals, semiotics language.

$$
\text { أستاذة مساعدة، كلية اللغة العربية، الجامعة الإسلامية العالمية، إسلام آباد. }
$$

* Assistant Professor, Faculty of Arabic, International Islamic University, Islamabad.

DOI: https://doi.org/10.52541/adal.v56i02.1101 


\section{Summary of the Article}

This research focuses upon the use of fables methodology and the underlying message carried through this technique. In this effort, another important aspect relating to semiotic and seminal values of the stories narrated by birds and other animals have been highlighted which hitherto remained overlooked. Distinctive style of the author out shines while making comparisons to state governance and politics vis-à-vis degrading morals and falling societal norms.

The research starts with a brief introduction, followed by elaboration of the concept of semiotics language and terminology used in the book. The research encompasses an analytical study of specific excerpts from the book, referring to different animals presented as representative community individuals. The article concludes with the summarized findings along with quoting sources and references.

After reading the supernatural stories in the book of kalīlä wa dimnä̈, I reached the following conclusions:

1- The semantic study in the role of animals in the story is nothing but an opening for other doors of semiotic understandings of our ancient literary heritage.

2- As for the title of the book, kalīlä wa dimnä, it is the gateway to cross-literary texts and open the mind to many questions.

3- It is a targeted criticism of kings, notables of the state and politics with symbols and metaphors.

4- The writer has presented animal characters imaginings of rulers and princes using various artistic and linguistic means.

5- As for the art of philosophy and wisdom through the literary style, it may perform an expressive function and an essential sign for the researcher to explore the depths of literary texts.

Superstitious literature is not only for entertainment and for fun, but is a fine literature in itself that embraces valuable education and lessons in the folds of symbols and metaphors if we try to reach them.

إنّ دراسات نظام العلامات في التراث العربي دراسة قديمة قدم الدرس اللساني، إلا أنّ 
الأفكار والتأملات السيميائية التي وصلت ظلت في إطار التجربة الذاتية لم تتجّسد في إطار التجربة

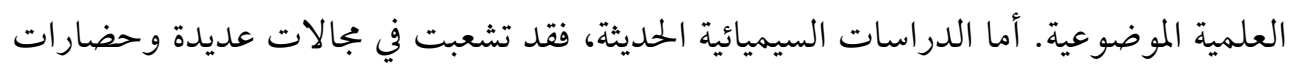

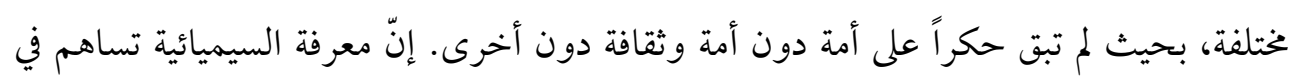

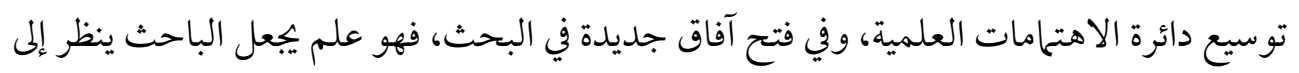

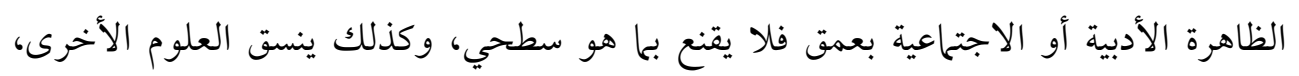
ويدرس الأشياء في توظيفها للعلامات.

أما كليلة ودمنة فهو مجموعة من الحكايات الرمزية على لسان الحيو انات التي تندرج ضمن

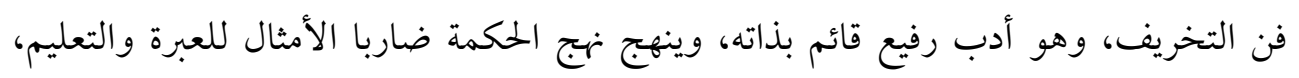

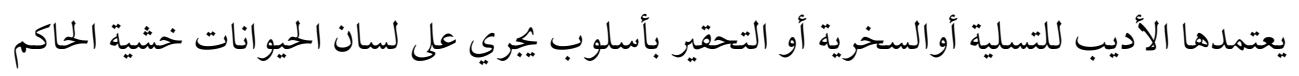
الظالم، حيث تستغل الحيو انات الحيلة لقضاء مآربها، كذلك الحكماء يصوغون الحيل من أجل القيل القيام

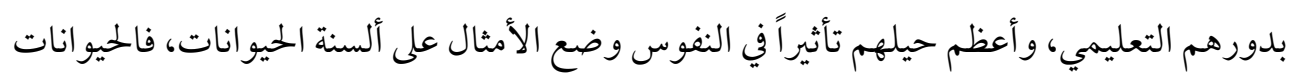

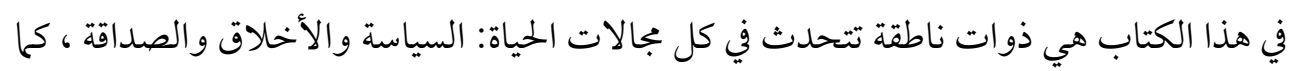

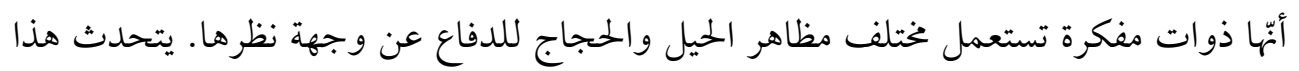
البحث عن الجوانب الرمزية والسيميائية ما تتضمن الحكايات من دور الحيوانات بإذن الله سبحانه

وتعلى. المبحث الأول: معنى السيميائية ولمحة موجزة عن المؤلف والتعريف بالكتاب أولا: معنى السيميائية لغةً واصطلاحا 1: في اللغة

السياء في معاجم اللغة: هي العلامة(1) أو الرمز الدال على معنى مقصود لربط تواصل

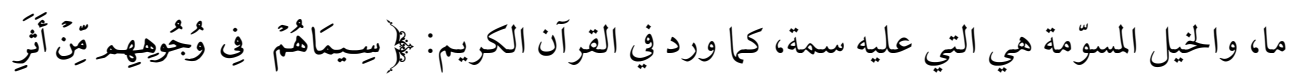
1 - محمد بن جلال الدين بن مكرم بن منظور، لسان العرب ( بيروت: دار صادر للطباعة والنشر، •99 م) صع^عـ. 


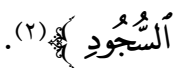

\section{r: معنى السيميائية اصطلاحاً}

السيمولوجيا دراسة جميع السلوكيات والأنظمة التواصلية، يعرّف سعيد بنكراد

السيميائية بأنها: دراسة حياة العلامات داخل الحياة الاجتحاعية (r). تجمع عدة كتابات ومعاجم لغوية وسيميائية على أنّ السيائية عبارة عن العلم الذي يعني بدراسة العلامات(ع)، كما ذكر السرغيني بأنه: "علم يدرس العلامة ومنظوماتها في رأي اللغات الطبيعية والاصطناعية كما يدرس الخصائص التي تمتاز بها علاقة العلامة بمدلولاتها، والعلامة هي الاصطلاح المركزي في

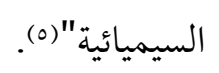

وحددها عادل فاخوري بأها: "دراسة الوسائل المستخدمة للتأثير والتواصل مع

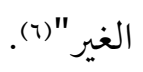

فقد توسعت مباحث السيميائية وشملت مختلف جوانب الحياة السياسية والاقتصادية

والاجتماعية والثقافية بل وحتى النفسية، ودخلت بشكل كبير ومباشر إلى المعطيات النقدية لما بعد

$$
\text { البنيوية. }
$$

$$
\text { ثانيا: لمحة موجزة عن حياة ابن المقفع }
$$

ولد ابن المقفع في قرية من بلاد فارس في مطلع القرن الثاني من الهجرة. فهو كان جتهدا

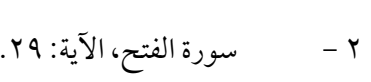

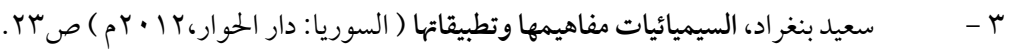

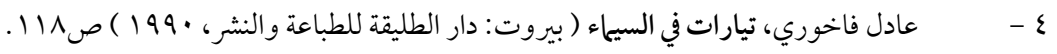

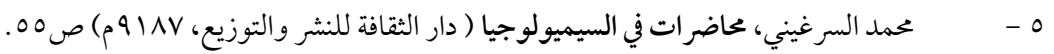

$$
\begin{aligned}
& 7 \text { - عادل فاخوري، علم الدلالة عند العرب: دراسة مقارنة مع السيمياء الحديثة (دار الطليعة للطباعة والنشر،1910 م) } \\
& \text { v }
\end{aligned}
$$


منذ الصغر، يحب العلم وتعلّم اللغات(V)، فدرس العربية وبرع فيها، وتعلم الفارسية واليونانية

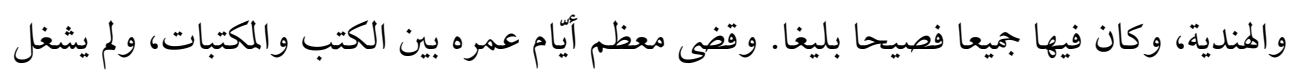

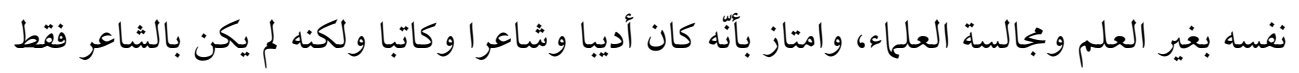
ليستجدي بشعره الخلفاء والأمر اء كما كان يفعل شعراء عصره، ولا كان من رجال اللغة وعلوم الكلام ليقوم بالتدريس في مجالس الأدب، ولا كان صاحب الصنعة ليعيش من خيرها، وإنّما كان

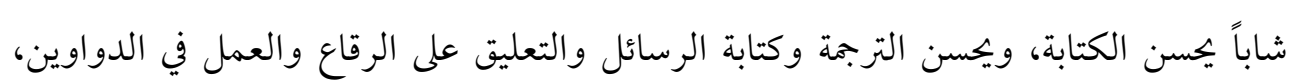
فتمكن من الوصول إلى الدواوين للعمل حسب ما يتناسب مع مؤهلاته.

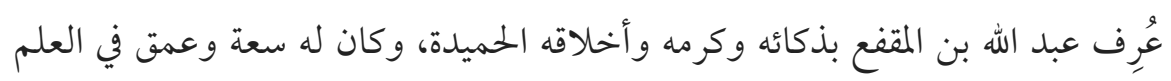
والمعرفة ماجعله من أحد كبار مثقفي عصره، حيث تتكون ثقافته من مزيج من ثلاثة جوانب:

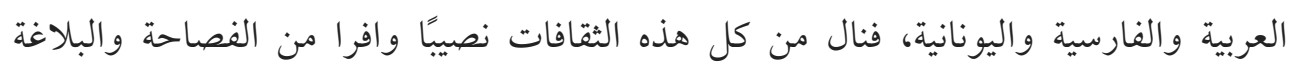
والأدب، ولا بد أن تكون ثقافته العربية أوفر بالتأكيد من ثقافته الفارسية، ليصل إلى ما وصل إليه

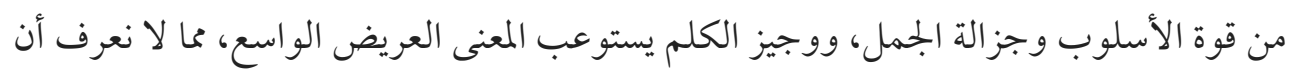
عنده مثله في لغته الفارسية.

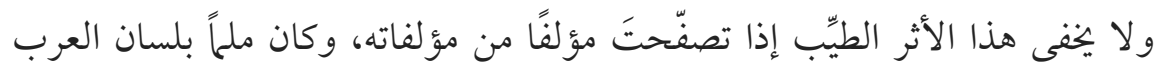

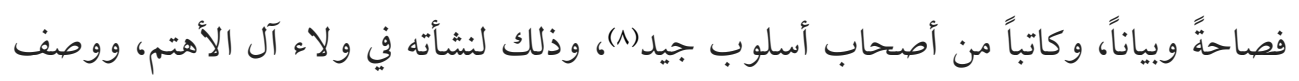

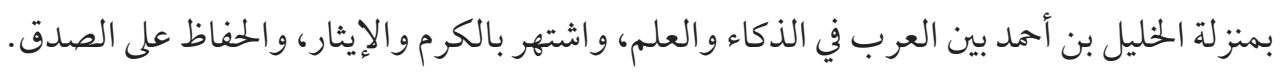

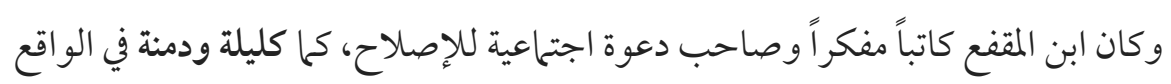
دعوة إصلاحية على ألسنة الحيو انات. وقد اتهمه حساده بفساد دينه، وربها كان الاتهّام من أسباب مقتله، ولا نجد في شيء من كتاباته ما يؤكد صدق هذا الاتهّام بل اختلف فيه المؤرخون.

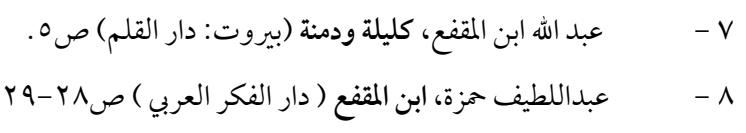


ثالثا: التعريف بالكتاب

يحتوي الكتاب على مجموعة من القصص الأخلاقية وضعت على ألسنة البهائم والطيور،

وحوت من الأخلاق والحكم، وتدور حول ما يجب أن يجري عليه الحكام في حكمهم وسياسة

دولهم. وسمي الكتاب باسم أخوين من بنات آوى، وهما كليلة ودمنة. قد أطلق الكاتب على

شخصيات القصة أسماء حيو انات، ويككي الكتاب حاكما ظالماً لشعبه، يذهب إليه فيلسوف يدعى بيدباء ليعطي له بعض النصائح ليصبح حاكما عادلا، ولكن الحاكم يمكم عليه بالسجن وبعد فترة يستدعي الحاكم الفيلسوف ليستمع منه النصائح، ويعده بتنفيذ كلامه، ويفك أسره، ويحوله إلى وزيره مما دفع الفيلسوف إلى تدوين هذه النصائح لتصبح مرجع الكلام. وقد اختلف المؤرخون في أصل الكتاب قال بعض بأن:

ابن المقفع ترجمه عن اللغة الفهلوية-اللغة الفارسية القديمة-إلى اللغة العربية(9). وذهب

بعضهم إلى أنّه اقتبس بعضه وترجم البعض الآخر. ولكن الأبحاث الدقيقة التي قام بها بعض المستشرقين قد أكدت بأنّ للكتاب أصولاً في اللغة الهندية واللغة السنسكريتية، ويقال إنّ ناقل الكتاب من الهندية راهب سريانى نقله إلى سريانية، وقد اعتمد على ترجمته دون الهندية. على الرغم من أنّ المؤرخين قالو ا بأنّ الكتاب قد كتب باللغة السنسكريتية ولكن النسخة الوحيدة التي وجدت هي النسخة التي كتبها ابن المقفع باللغة العربية، وهناك رواية أخرى تفيد بأنّ ابن المقفع هو من كتبها ولكنّه خاف من الحبس والإعدام ، ولذلك ادّعى بأنّه ترجمها فقط من القصة الأصلية. هو كتاب فيه كنوز من الحكمة الشرقية(·)، كما اجتمع فيه دفينة من الفضائل والعبر والحكم والأمثال، وهو امتزاج بين أدب الشرق وحكمه وفلسفة الإغريق ونظمهم بأسلوب أدبي رائع، بألسنة البهائم والطيور الذي يدفع المتلقي إلى استنباط بها يحتوي عليه النص والعنوان من

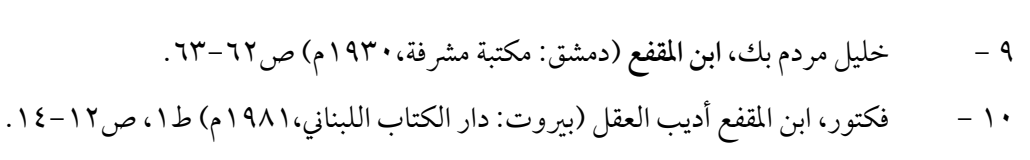


إبداع فني وما يرتبط بالمؤلف وبيئه والتناص مع النصوص الأخرى، الذي قد يسمى الدراسة

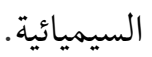
المبحث الثاني : الدراسة السيميائية للكتاب ولدور الشخصيات الحيوانية أولا: الدراسة السيميائية للكتاب

أحدث عنوان الكتاب وما فيه من العناصر الفنية جملة التساؤلات عبر مستوياته المدروسة

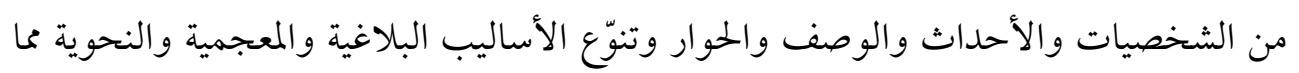
شحذ فينا روح المغامرة ودوافع التحفيز لمعرفة ما ترمز إليه دلالات البنية العميقة، كما جعل شخصية الفيلسوف أن يبحث المتلقي وينفصل ويتلذذ في كشف ما يرمي إليه النص في بنيانه الداخلية، ويحفر عن شفرات النصوص، ووسائل العلامات، وسياء الشخصيات وصور انبعاثها في النص، و البناء الفني الذي يثير الطموح و الرغبات لكل من القارئ و السامع (11). شخصيات الكتاب حيوانات برية، فالأسد يلعب دور الملك المتعجّل المفتقر للمعرفة والحكمة والمتحكّم لسلطة الجسد حسب منطق القوة دون قوة المنطق، والثور خادم الملك تابع معدوم الشخصية مستغل واسمه شتربة، وابن آوى وهورمز المكر والخديعة، عقله يعمل بالشر لابالخير، كليلة ودمنة رمز لدورهذا الحيوان الشرير. وشخصيات أخرى عديدة، وليست هذه الشخصيات الحيوانية إلا وسيلة فنية وظّقها ابن المقفع لنقد الواقع الفكري والأخلاقي والسياسي، وسعى إلى إصلاحه بطريقة مباشرة متوسلا

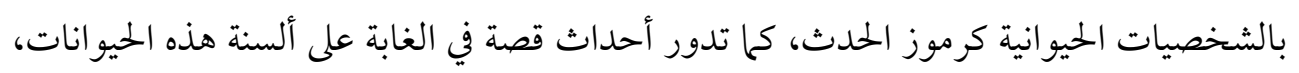
حيث ترمز هذه الحيوانات إلى شخصيات بشرية في الأصل، وهي قصة العلاقة بين الحاكم والمحكوم. 


\section{ثانيا: الدراسة السيميائية لدور الشخصيات الحيوانية}

تعد الشخصية جزءًا أساسياً في بناء القصة، فهي منبع الحدث والشعور، فثمة علاقة وطيدة بينها والحدث، فالشخصية هي صاحبة الفعل والدافعة إلى الحدث، وهي مصدر المشاعر التي تمثل لباب القصة الأساسي (rا). فتمتلك الشخصيات بأسهائها وصفاتها وخلجاتها طاقات إيحائية، ودلالات معينة، فإنّ أفضل تعبير عن العاطفة والشعور إنّما يكون باللغة المشتر كة بين أفراد الجماعة، فالشخصية تعطي القصة أو الرواية بعدها الحكائى، وتقود الأحداث وتنظّم الأفعال (rا). فمن أهم الشخصيات:

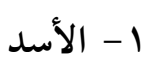

من أهم شخصيات القصة هو الأسد؛ رمز من الرموز التي تتحقق الجدلية والصراع للضعف السياسي والأخلاقي الذي يريد الكاتب عن تعبيره، لأنّ الرمز يعد في الأدب وسيلة تعبيرية جمالية من جهة، وقوة نصية تصنع المعنى من جهة ثانية، وفهم النص ليس من سهل بل يتوسل القارئ مقاربة النص وفق سيمياء الدلالة، وتعد سيمياء الدلالة بحثاً عن قراءات دفينة في أغوار النص (ع) ). فسيمياء لدور هذه الشخصية في النص: "زعموا أنّ أسداً كان في أرض كثيرة المياه والعشب، وكان في تلك الأرض من الوحوش في سعة المياه و المرعى شى عُ كثيرّ، إلا أنّه لم يكن ينفعها ذلك لخوفها من الأسد، فاجتمعت وأتت إلى الأسد، فقالت له: إنك لتصيب منا الدّابّة بعد الجها والتعب، وقد رأينا لك رأيا فيه صلاح لك وأمن لنا، فإن أنت أمّنَنَا و لمُ ثُخِفْنا فلك علينا في كل يوم دابّة نرسل بها إليك في وقت غدائك، فرضي

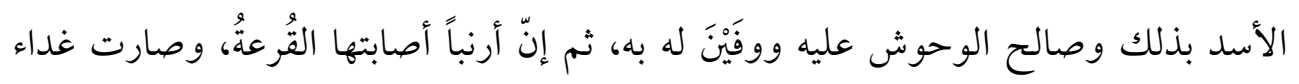

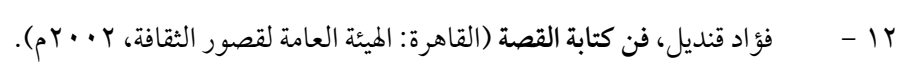

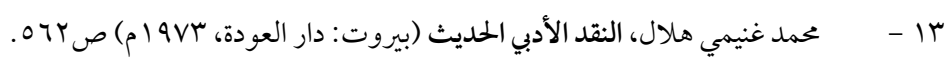

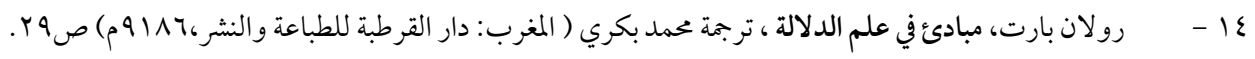


الأسد، فقالت للوحوش: إن أنتم رفقتُنَّ بي فيال لا يضرّكن رجوت أن أريخكُكُّنَ من الأسد، فقالت

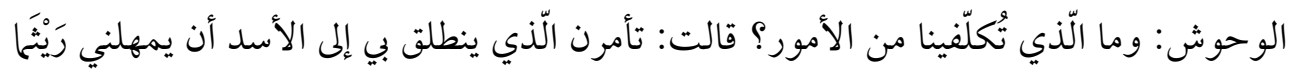

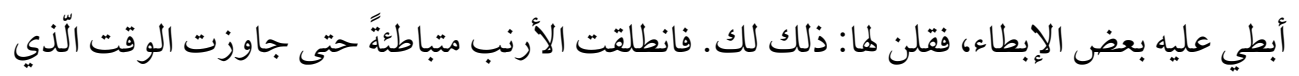

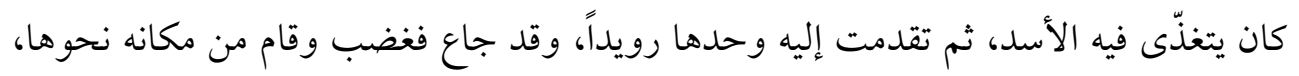

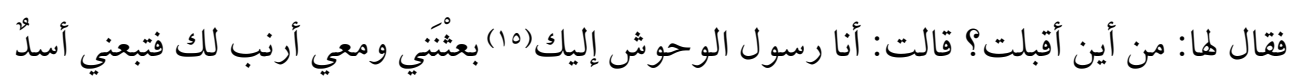

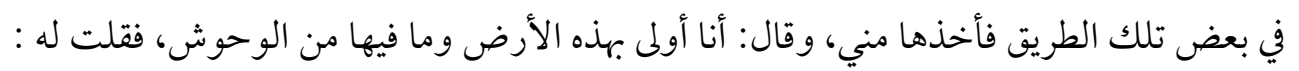

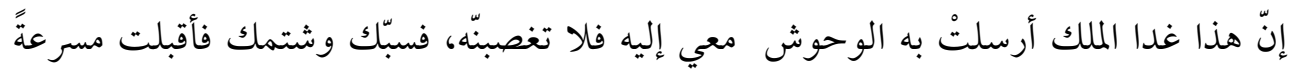

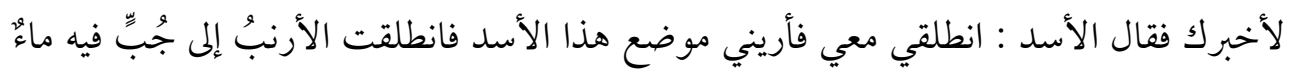

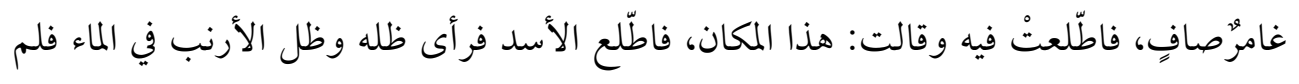
يشك في قولما ووثب إليه ليقاتله فغرق في الجِبّ، فانقلبت الأرنب إلى الوحوش وأعلمتهنّ صنيعها

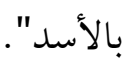
في هذا النص المذكور شخصية الأسد من أهم الشخصيات الحيوانية، وأهم الرموز السيميائية الني يعنى بها البحث، ولذا، كان الأسد يعد رمزا من رموز القوة والسطوة منذ العصور القديمة (17)، وهو يعد من الحيوانات المفترسة المعروفة بقوتها البدنية وأسنانها القوية، إذ يعد الأسد

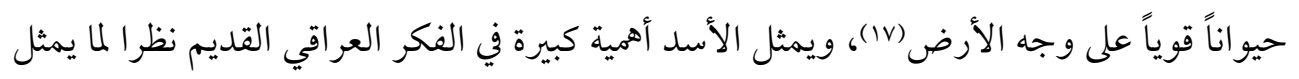

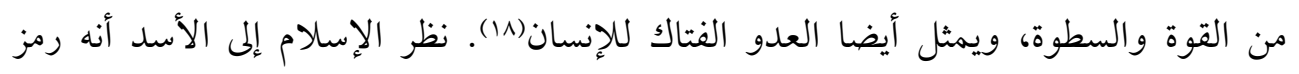
للشجاعة والقوة ويسمى العرب الرجل الشجاع بالأسد.

\footnotetext{
10 - عبد الله ابن المقفع، كليلة ودمنة ( بيروت: دار القلم ) ص90.

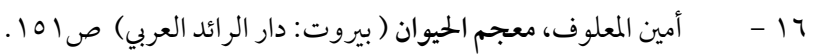

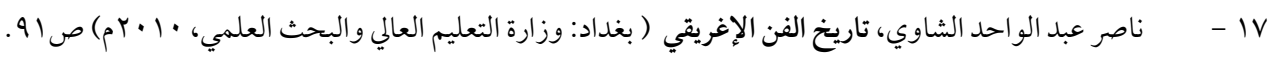
11 - علي وائلة، من الطيور والحيوانات البرية في العراق (بيروت: موسوعة البيئة العراقية، مركز دراسات الأمة

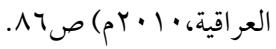


أما ابن المقفع فهو يتّخذه رمزا لملك ضعيف عقلاً ورأياً وفكرةً، على الرغم من القوة البدنية والسطوة والملك العظيم والهيبة والرعب على كل من يهكم عليه من الرعية والأعوان

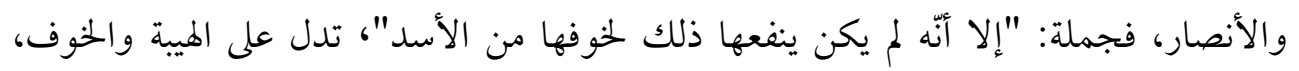

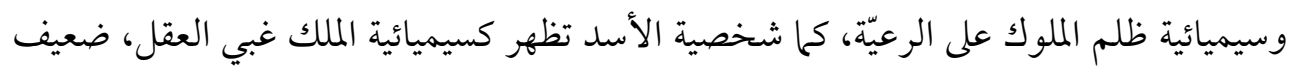

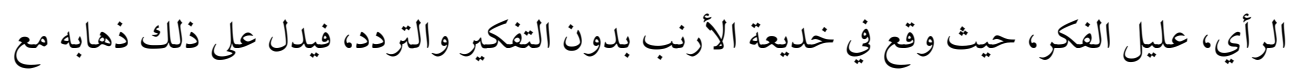

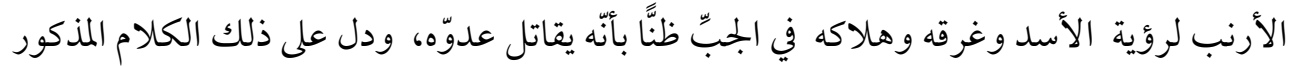
في النص بأن الأسد قال: "انطلقي معي فأريني موضع هذا الأسد، فانطلقت الأرنبُ إلى جُبِّ فيه

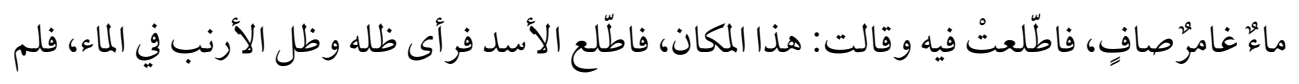
يشك في قولها ووثب إليه ليقاتله فغرق في الجِبِّ"(19) كما أسلوب الأمر :(انطلقي)، و (فأريني ) يرمز

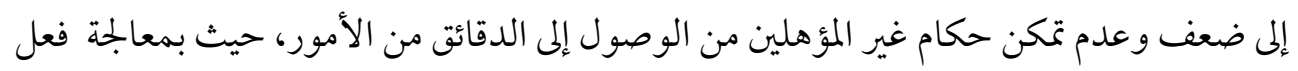

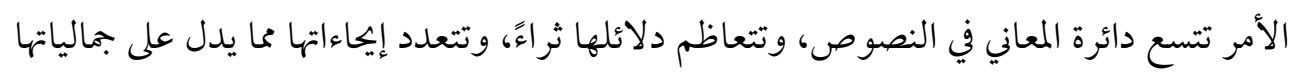
وتنوع التجاهاتها. أما دور الأرنب فهو دور أحد من المصلحين والمحسنين من أعيان وأنصار الحكومة، لأنّ

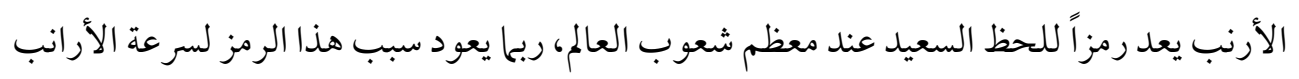

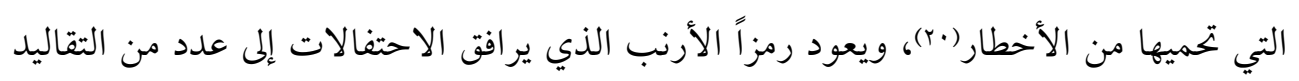

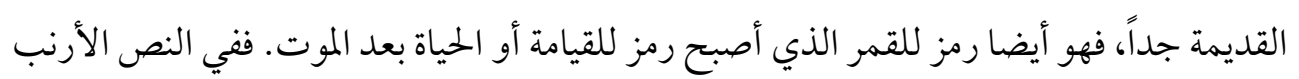

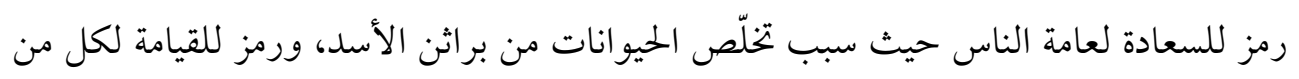

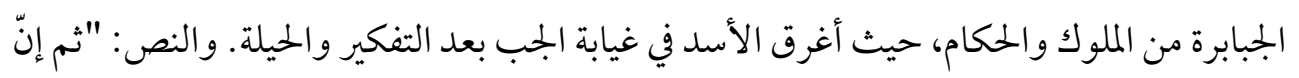

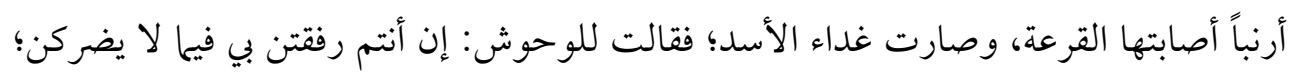

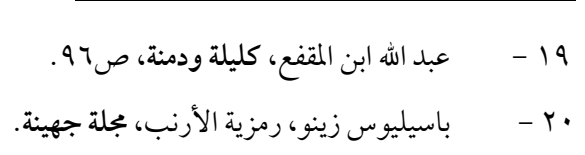




$$
\text { رجوت أن أريككن من الأسد". }
$$

يدل على حكمته وفطانته وغاية إدراكه الأمور قبل تعاظمها، فكلمة " أريككن" بمعانيها: اطمئنان، استراحة، الهدوء، السكون، تدل على حكمته وفطانته التي فطن بها الصراع النفسي لكل من يرافقها من الوحوش والحيو انات حتى نجح في الوصول إلى غاياته، واستخدامه فعلا متعديا يفيد للتشاور في الأمور السياسية ولصالح الرعية.

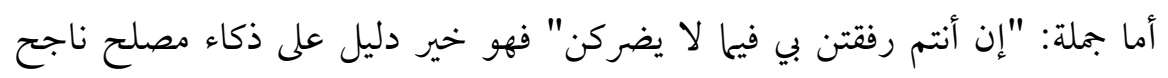
ومخلص، لأنّ أداة الشرط (إن) تستخدم مع الأمور التي يشك في وقوعها أو يندر وقوعها(rr)،

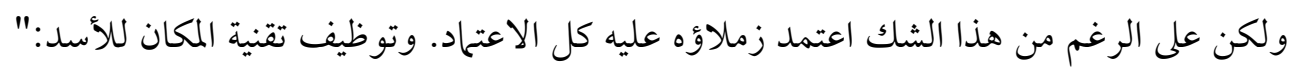

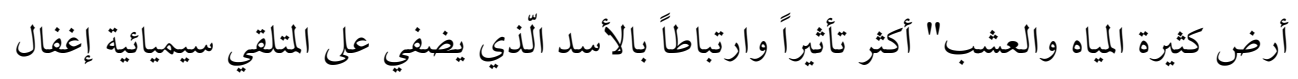
الملوك و إهمالهم عن رعيتهم بالإضافة إلى سيميائية تمكن الملوك وأعيان الدولة على الكنوز و الخز ائن،

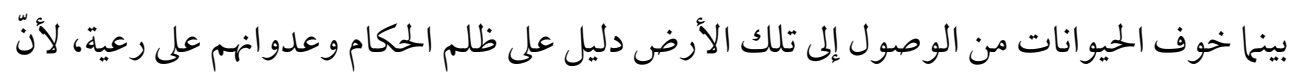

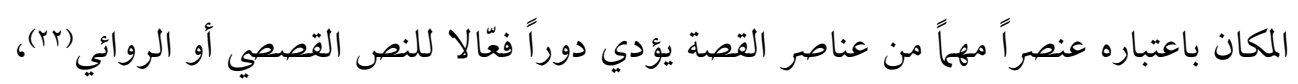

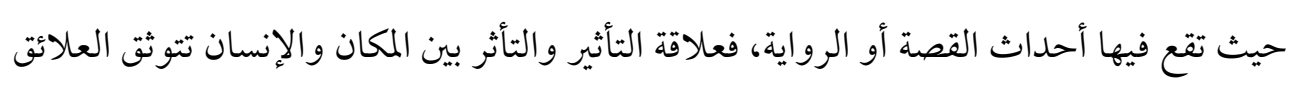
بينها. هكذا دلالة الجمل في النصوص تؤدي دورا أساسياً لجماليتها وإدراك ما فيها من الرموز والدفائن، أما الجمل الاسمية في النص فهي ترصد حالتين متصارعتين حالة وفرة المال وكثرته،

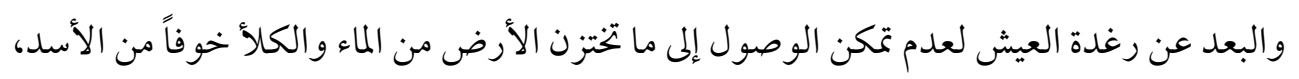

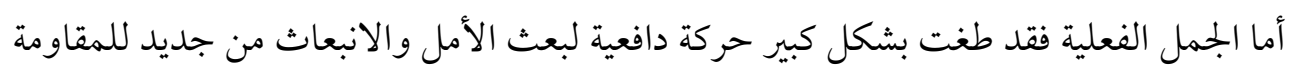

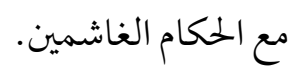

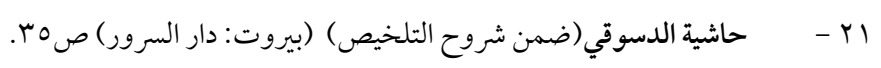

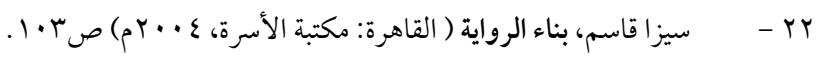

$1 \leqslant 1$ 


$$
\text { r }
$$

قال كليلة: "إن قدرت على هلاك الثور بشيء ليس فيه مضرة للأسد فشأنك، فإنّ الثور قد أضرّ بي وبغيرنا من الجند وإن أنت لم تقدر على ذلك إلا بهلاك الأسد فلا تقدم عليه فإنّه غدر مني ومنك. ثم إنّ دمنة ترك الدخول على الأسد أيّاما كثيرة، ثم أتاه على خلوة منه، فقال له الأسد: ما حبسك عني؟ منذ زمن لم أرك ألا لخير كان انقطاعك؟ قال دمنة: خيراً فليكن أيها الملك، قال الأسد: وهل حدث أمرّ؟ قال دمنة: حدث ما لم يكن الملك يريده ولا أحد من جنده. قال: وما ذلك؟ قال كلام فظيع، قال أخبرني به، قال دمنة: إنه كلام يكرهه سامعه، ولا يشجع عليه قائله، وإنك أهها الملك لذو فضيلة، ورأيك يدلك على أن يوجعني أن أقول ما تكره، وأثق بك أن تعرف نصحي وإيثاري إيّاك على نفسي، وإنّه ليعرض لي أنّك غير مصدّقي فيها أخبرك به، ولكني إذا

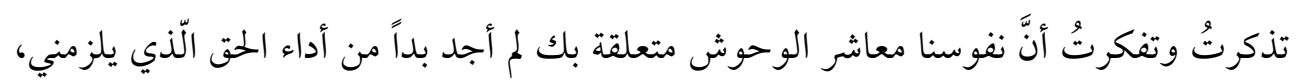
وإن أنت لم تسألني، وخفت ألا تقبل مني، فإنّه يقال: من كتم السلطان نصيحته والإخوان رأيه فقد خان نفسه، قال الأسد: فها ذاك؟ قال دمنة: حدثني الأمين الصدوق عندي أن شتربه خلا برؤوس جندك، وقال قد خبرت الأسد، وبلوت رأيه ومكيدته وقوته، فاستبان لي أن ذلك يؤول منه إلى

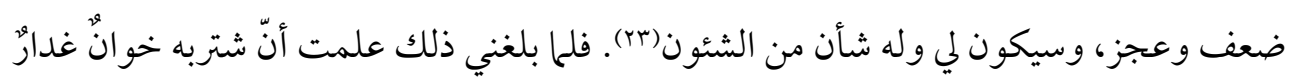
وأنّك أكرمته الكرامة كلها، وجعلته نظير نفسك، وهو يظن أنه مثلك وأنك متى زلت عن مكانك صار له ملكك ويدع جهداً إلا بلغه فيك، و قد كان يقال: إذا عرف الملك من الرجل أنه قد ساواه في المتزلة والحال فليصرعه، فإن لم يفعل به ذلك كان هو المصروع. وشتربة أعلم بالأمور وأبلغ فيها و العاقل هو الذي يحتال للأمر قبل تمامه ووقوعه"(ع). في هذا النص شخصية الثور و شخصية الدمنة( أحد من ابن آوى) شخصيتان مهمتان،

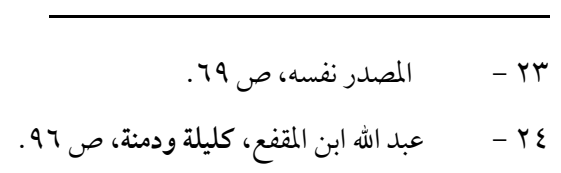


أما الثور فهو كان يرمز إلى القوة والحكمة والشجاعة والسمو في الحضارة الرافدية(ro)، و في مصركان يرمز إلى القداسة والفطانة، فهنا رمزللشخصية المخلصة للملك والرعية، الذي اكتسح مكان الاعتحاد والوفاء عند الملك بخدمته وحكمته وبصيرته، فدليل على ذلك:" وأنّك أكرمته

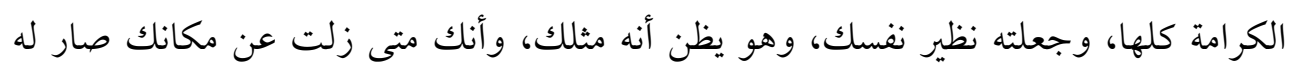

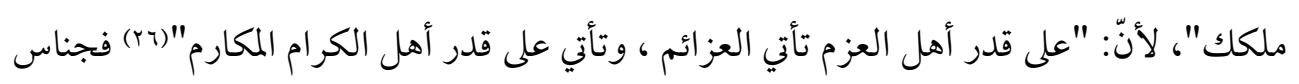

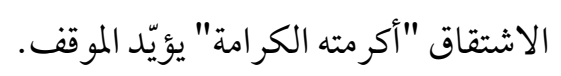

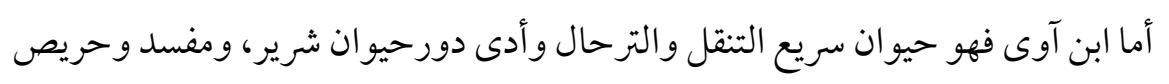

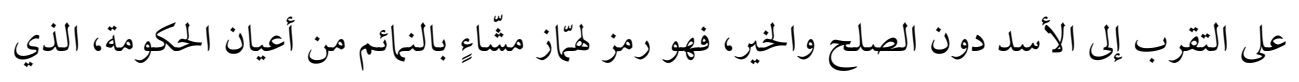
يريد اكتساب المعالي دون الجد والكد، بل بالحيل والمكر والتملق والمجاملة يفسد بين الملوك وبين وبين الأنصار و الأعوان، فدليل على ذلك قوله: "قال دمنة إنه كلام يكرهه سامعه، ولا يشجع عليه قائله.

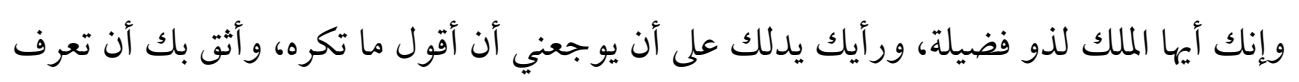
نصحي وإيثاري إياك على نفسي". فهنا تكرار ضمير المتكلم مقترنا بضمير المخاطب يدل على القوة والاتِّاد، والوحدة

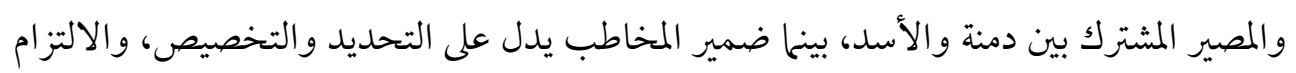

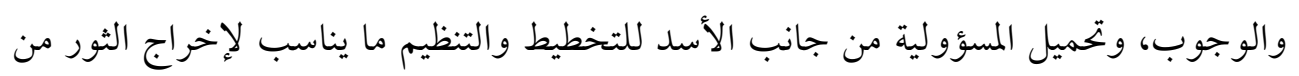
حلقة الملك ومن أعوانه وأنصاره، حتى نجح دمنة في مكره وحيله باستخدام هذا الأسلوب المؤثر الجذاب.

هذه سيميائية لشخص مكار وخديع من أعوان الملوك والحكماء وأنصارهم، الّذي يشتت الشمل ويفرّق الجمع والعلاقة ما بين الحكومة والرعية بالتملق والمجاملة، إذ تمتلك الحروف مهرف

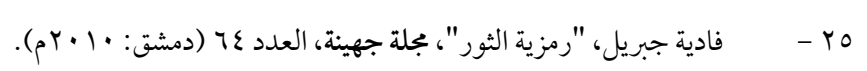
TY - هذا من أهم و أشهر قصائد المتبي التي نظمها في مدح سيف الدولة معجبا بشجاعته وكرمه ونبل أخلاقه. 
والألفاظ هوية دلالية تجسّد أحاسيس وأفكار وسلوكيات مسبّة ومحايثة لذاكرتها قبل توظيفها في

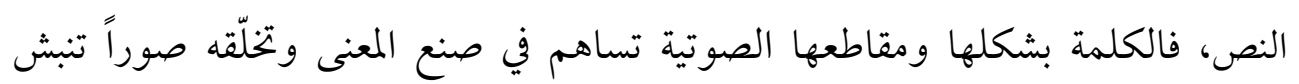
أخرى، وتشدّنا إلى ما لم تلامسه الكلمات (rv).

واستخدام تقنية المكان للقاء ما بين الأسد و الدمنة " ثم أتاه على خلوة منه " أكثر ما يلائم

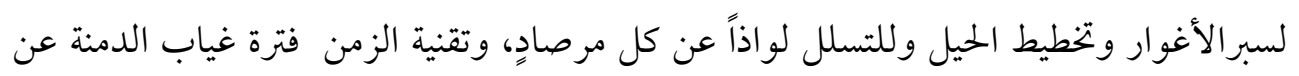

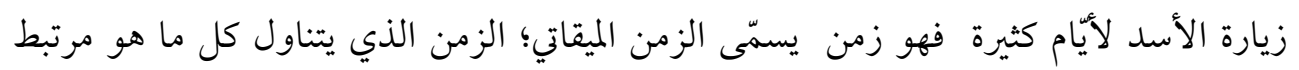

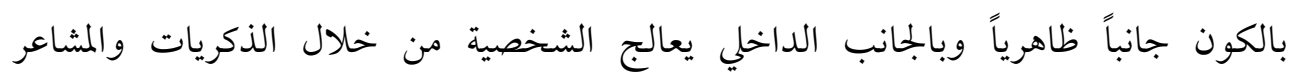
والأحاسيس، فهو يشمل كل ما هو كوني ويتضمن الفصول والشهور والأيّام، والمؤشرات الزمنية،

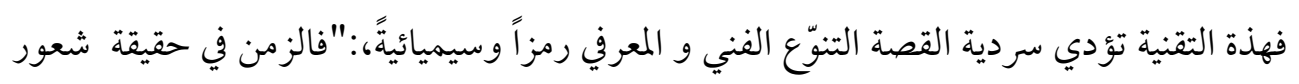

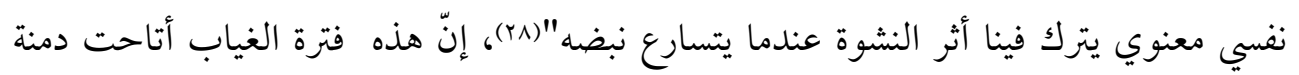
التخطيط للحيل والمكر ضد الثور، بينما زاد الأسد تشويقاً وحرصاً خلال الفترة.

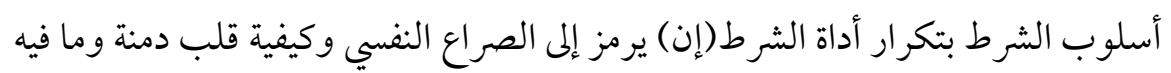

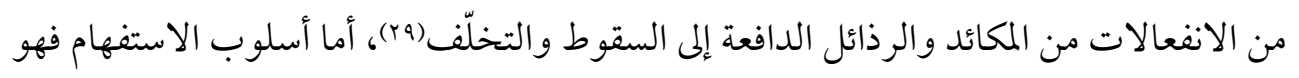

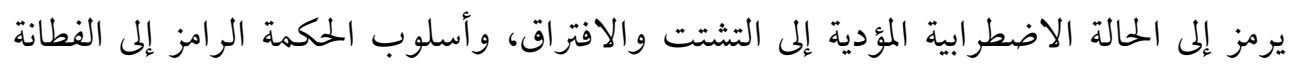

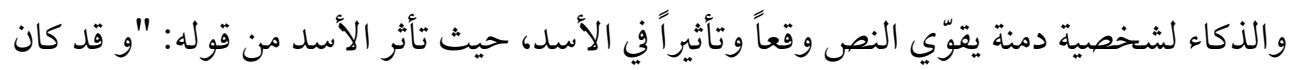

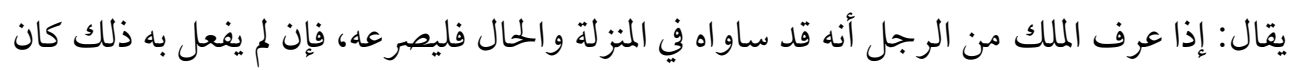

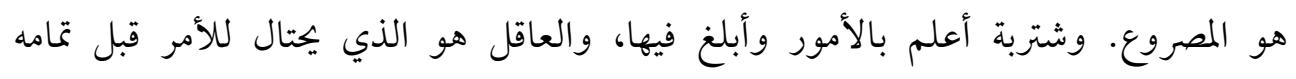

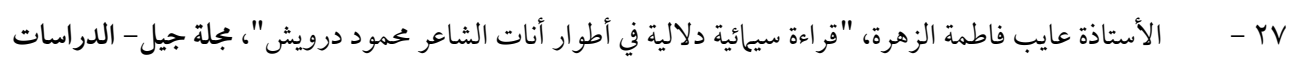

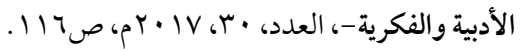

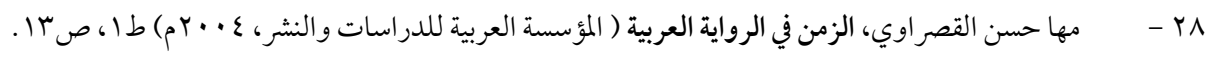

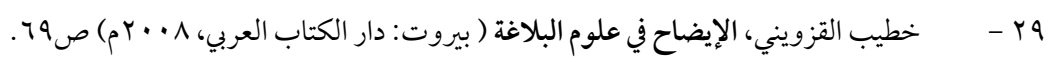




$$
\text { ووقوعه" (r). }
$$

الغراب رمز للفراق والموت، والغراب مثلاً سلبيا في الثقافة العربية لشدة سو اده، قد سماه العرب القدماء غراب البين وفراق المحبين(1)، والغراب من أحذر الطيور وأحزمها، كما يقال: فلان أحذر من الغراب، فأثبت الدراسات العلمية أن الغراب هو أذكى الطيور و أمكرها على الإطلاق، ويعلل ذلك أن الغراب يملك أكبر حجم لنصفي دماغ بالنسبة إلى حجم الجسم في كل الطيور المعروفة. ففي هذه القصة قد أدّى الغراب دور الذكاء والحزم والبصيرة، سياءُ ورمزا لوزير ملك أو مشير له، يعتمد عليه الملك على حسن تدبره وذكائه وبصيرته، ويستشيره عند المكاره وعندما تكالب عليه ما يجاوره من الأعداء، فيدل عليه التشاور والتحاور ما بين الملك و الغربان حول مهاجمة البوم والمدافعة عنها ما كان يتوقع بعد ماوطئت عليها أراضي الجيران ظلماً وعدواناً، فنكتفي بنقل قليل من نصوص القصة من باب (البوم والغربان) من الكتاب:

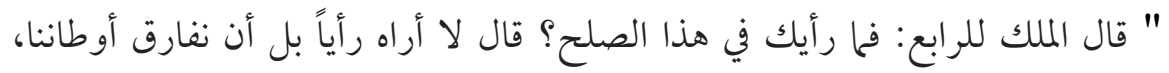
ونصبر على الغربة وشدة المعيشة خيرٌ من أن نضيع أحسابنا، ونخضع للعدو اللّي نحن أشرف منه،

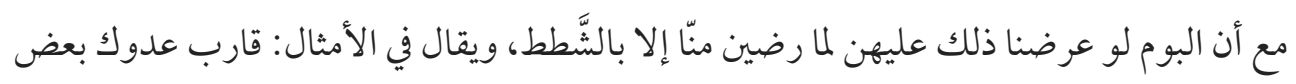

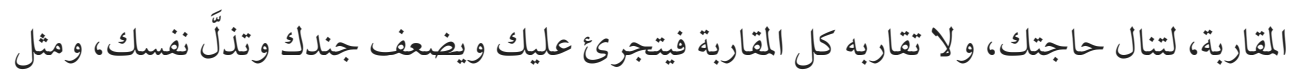
ذلك مثل الحشبة المنصوبة في الشمس، إذا أملتها قليلاً زاد ظلها، وإذا جاوزت بها الحد في إمالتها

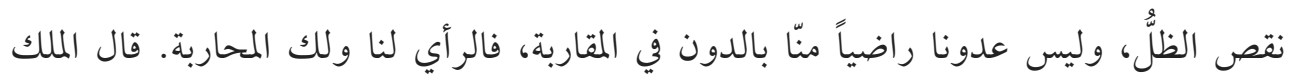

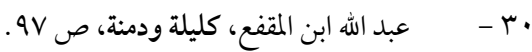

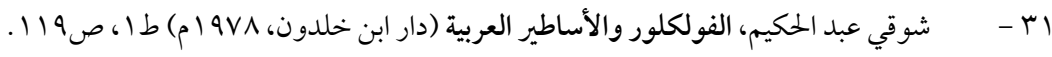

$1 \leqslant 0$ 
للخامس: ما تقول أنت؟ وماذا ترى: القتال أم الصلح أم الجلاء عن الوطن؟ قال: أما القتال فلا سبيل للمرء إلى قتال من لا يقوى عليه وقد يقال: إنه من لايعرف نفسه وعدوه وقاتل من لا يقوى

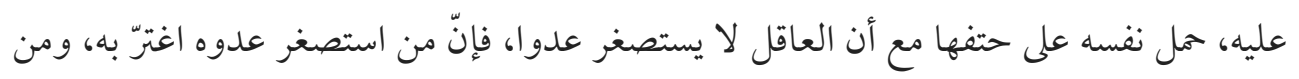

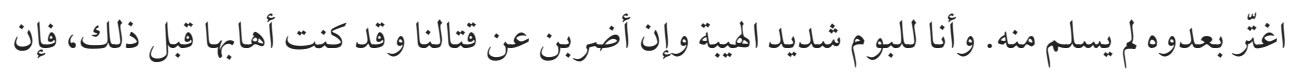

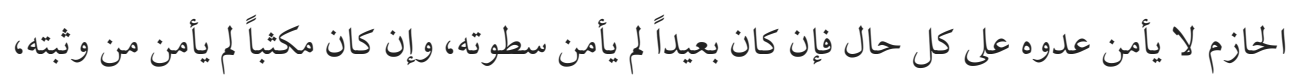
وإن كان و حيداً لم يأمن من مكره" (rr).

تبدأ القصة بخلفية الجبال وشجرة الدوح، خلفية الجبال ترمز إلى الشرف والكرم لمن يمتلك هذا الفضاء المكاني، وشجرة الدوح سيميائية اليسر والرخاء لمن يجاور هذا الحيز المكاني.

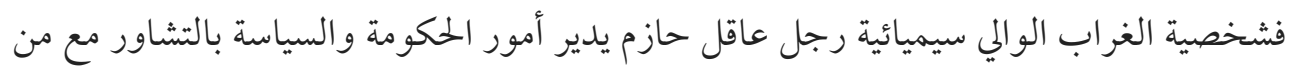
يرافقه من المسئولين. قد نجح الكاتب في تقديم هذه السيميائية بكل الوضوح مستخدما أسلوب

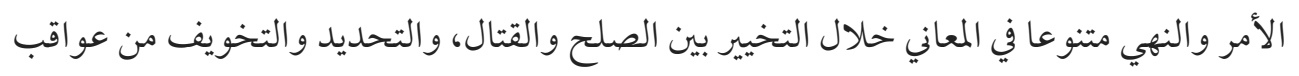
القتال، والنصح والإرشاد لكل من ألقى إليه السمع. بالإضافة إلى ذلك تنوعت الأساليب البلاغية في النص ضمن إليه قالب استعاري وبجازي،

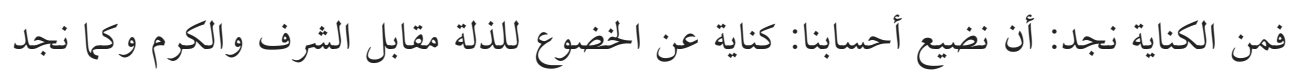

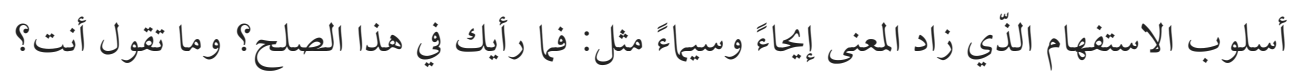

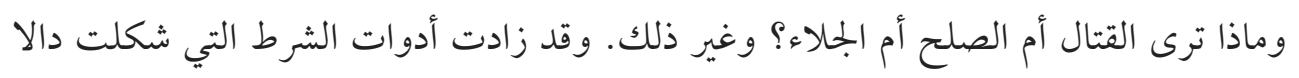
محورياً تعلقت بها جملة الحوار ومدلو لاته مثل: "من استصغر عدوه اغترّ به ومن اغتّر بعدوه لم ميسلم

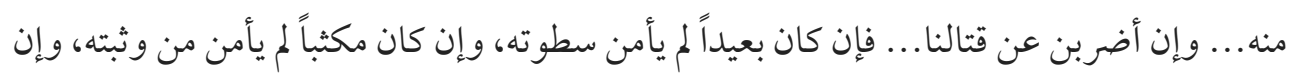
كان وحيداً لم يأمن من مكره" (rr).

\begin{tabular}{|c|}
\hline عبد الله ابن المقفع، كليلة ودمنة، ص 10 10 \\
\hline المصدر السابق، ص 100 . \\
\hline
\end{tabular}


هكذا تراوحت الجمل الفعلية والاسمية حيث ترصد الجمل الاسمية حالة السكون من خلال تصوير الحالة المأسوية وحالة اليأس بعد الإغارة من البوم، كما الجممل الفعلية مخلّة حركة دافعية لبعث الأمل والانبعاث من جديد للمقاومة مع البوم. فالجناس المشكل للتضاد ناجم عن

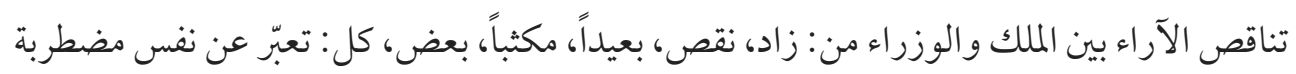

$$
\begin{aligned}
& \text { غير مو افقة على من سو اه. } \\
& \text { ـ - الأرنب }
\end{aligned}
$$

شخصيات الأرانب عببة للأطفال، وهي رمز للوداعة والهدوء، كما يضرب بها المثل في

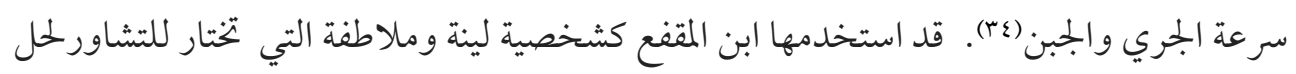

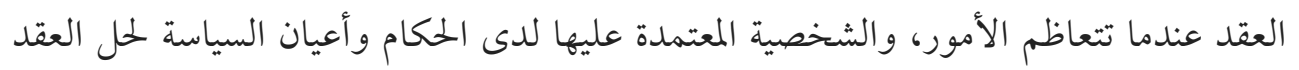

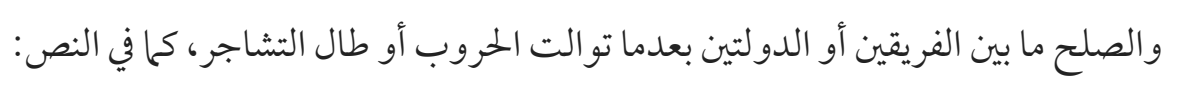

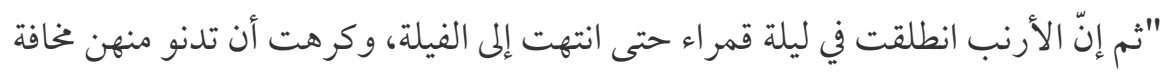

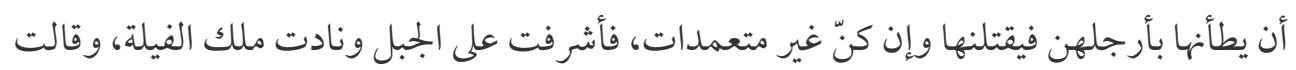

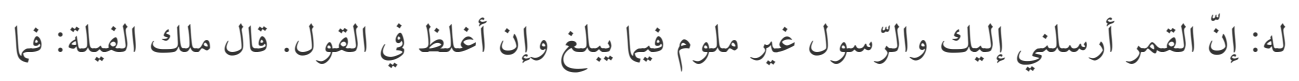
الرسالة؟ قالت: يقول لك إنّه من عرف فضل قوّته على الضعفاء فاغتّر بذلك في شأن الأقوياء قياساً

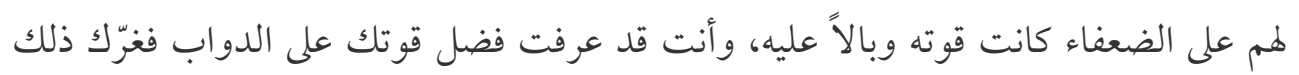

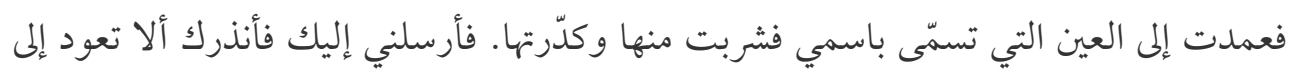

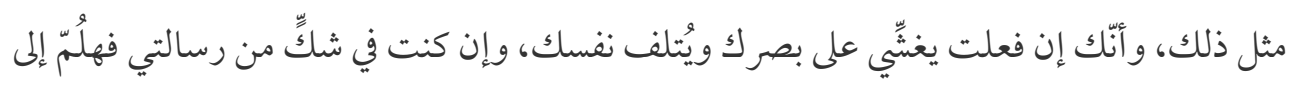
العين من ساعتك فإنّه مو افيك بها، فعجب ملك الفيلة من قول الأرنب فانطلق إلى العين مع فيروز

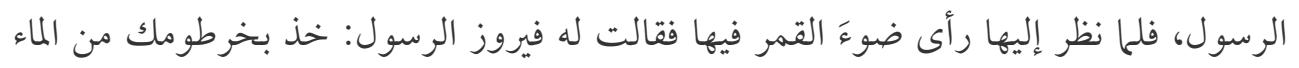

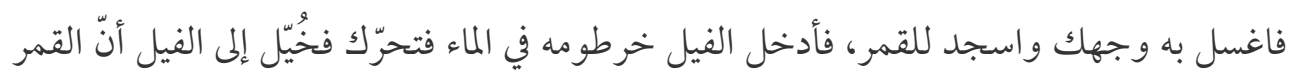

$$
\text { ع - - باسيليوس زينو، "رمزية الأرنب"، بجلة جهينة (دمشق). }
$$


ارتعد، فقال: ما شأن القمر ارتعد أتراه غضب من إدخالي الخرطوم في الماء؟ قالت فيروز الأرنب:

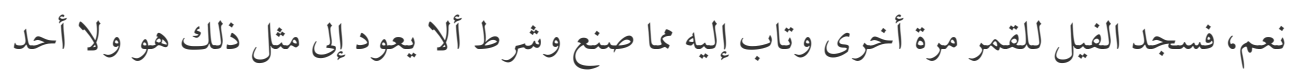

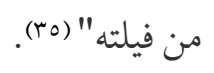

فهذا النص:" وكرهت أن تدنو منهن مخافة أن يطأنها بأرجلهن فيقتلنها وإن كنّ غير

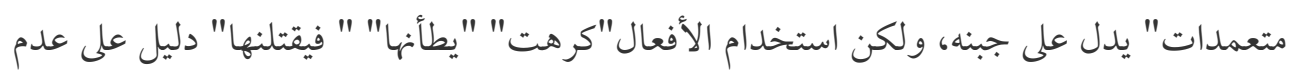

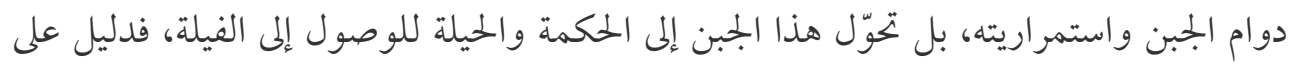

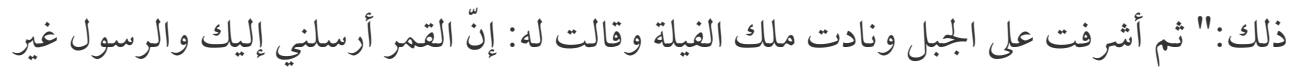
ملوم فيما يبلغ، وإن أغلظ في القول"، محاولته لإقناع الفيلة للذهاب معه إلى العين تدل على حكمته وهدوئه. و تقنية الزمان(ليلة قمر اء) تقنية محورية تترتب في القصة عناصر التشويق والإيقاع(ج).

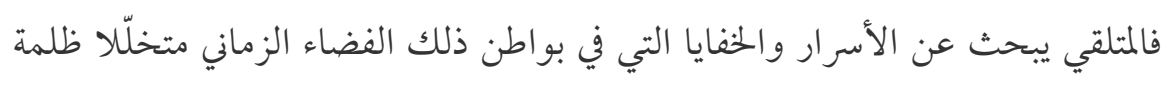

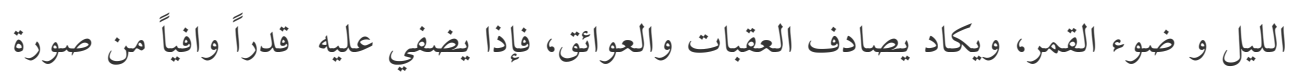

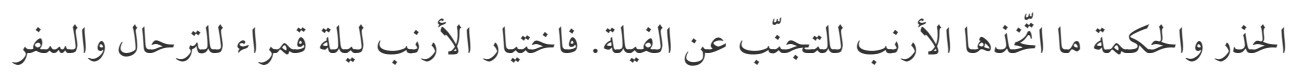

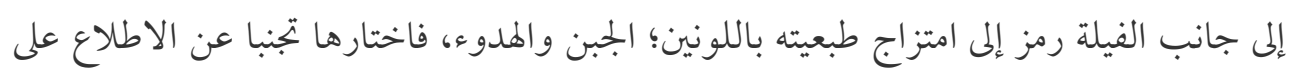

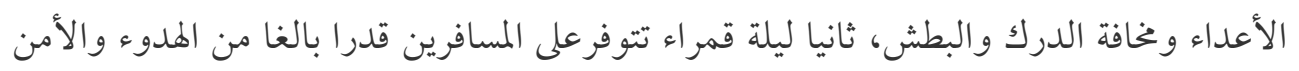

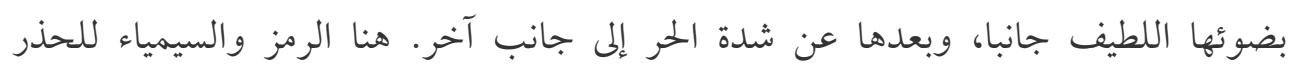

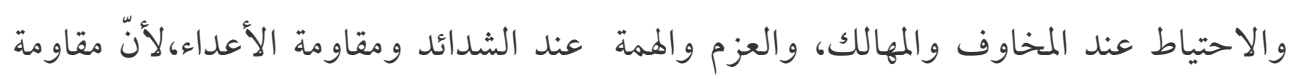
الضعفاء مع الأقويا لا تحتاج إلى القوة الظاهرية بل تحتاج إلى الحكمة و والبصيرة، كما نرى في النص:

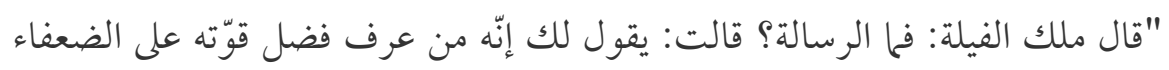

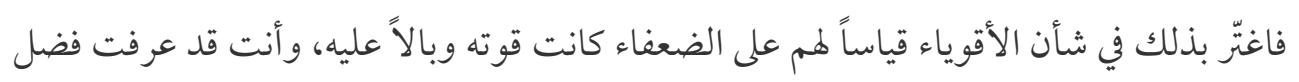

$$
\begin{aligned}
& \text { م - - عبد الله ابن المقفع، كليلة ودمنة، ص101. }
\end{aligned}
$$

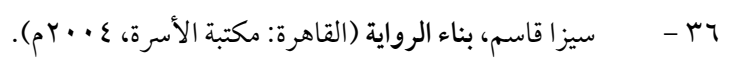


قوتك على الدواب فغرّك ذلك فعمدت إلى العين التي تسمّى باسمي فشربت منها وكدّرتها،

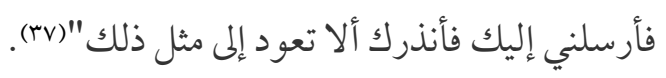

أما تقنية المكان المفترض(الجبل) و (العين) فتتوفر بها يحويه من الواقع من دلالات إيحائية

رمزية وتصويرية، وتربط بما فيه من الجماليات الطبيعية الناجمة من تناقض شدة الجبل الجبل وثباته جانباً،

ورقة الماء ولطفه إلى جانب آخر، ترمز إلى الحالتين المتناقضتين بين الرعاية وبين أعيان الدولة

$$
\text { هـ الملوك. }
$$

تتمحور رمزية الثعلب في الثقافة الصينية حول الحياة الآخرة، وكان يُعتقد بأنّ رؤية

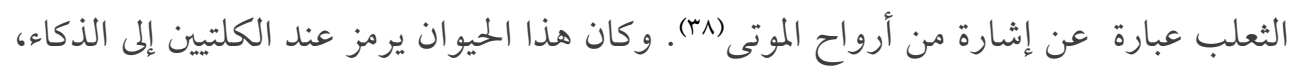

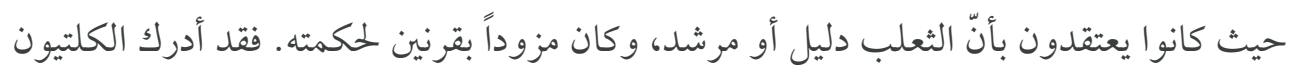

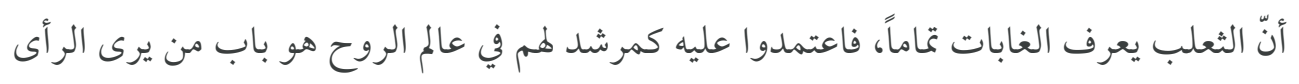

$$
\text { لغيره ولا يراه لنفسه. }
$$

أما ابن المقفع فقد استخدمه كواحد من أعيان الدولة والسياسة أو عضو من أعضاء المؤسسات والهيئات الذي يرصد كل المرصد ليختطف لنفسه كل ما يقع في يده دون المصالح والعون لمن يمدّ يد العون أمامه، ويكافح كل المكافحة والنضال و الحيل والمكر للوصول لـول إلى ما تغرّه نفسه، يتمكن من التقرب إلى أعيان الدولة والحكومة بكل الثقة والاعتماد بالتمالك والمجاملة

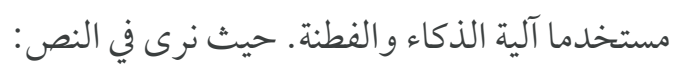

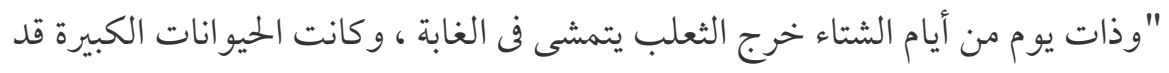

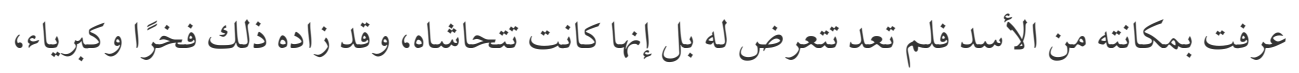

$$
\begin{aligned}
& \text { MV }
\end{aligned}
$$

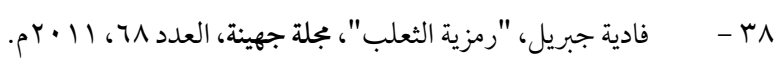

$1 \leqslant 9$ 
وفجأة التقى بأحد زملائه القدامى من الثعالب الضعيفة المتهالكة فألقى عليه السلام لكنه لم يرد،

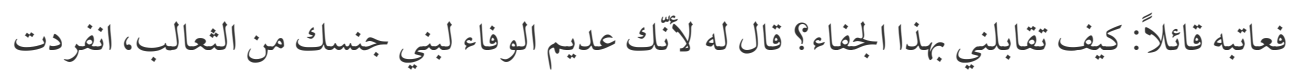
وحدك بالغنيمة وتركتنا نموت من البرد والجوع واحتقار حيوانات الغابة لنا، عندئذ تذكر ماضيه

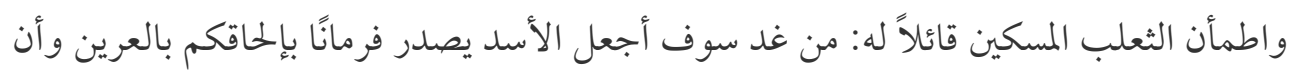
تنعموا بخيراته، وألا يتعرض لكم أحد بسوء ومن يفعل ذلك مها كانت قوته سوف يكون جزاؤه

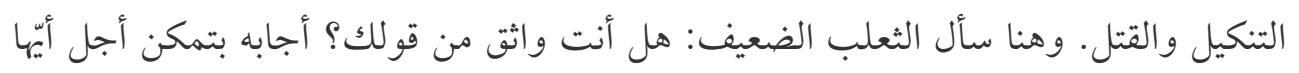
الغبي فقد تمكنت تمامًا من عقل الأسد وسيطرت على أفكاره وأصبحت أوجه مشاعره إلى حد، أنّه لم يعد يقدم على افتراس حيوان آخر إلا بعد مشاورتي". في هذا النص المذكور مظهر الثعلب يدل على مكانته عند الملك، حيث اللافظ و الملفوظ كلاهما يؤيّدان مكانته عند الأسد، وحسن ذكائه وغباوة الأسد، وعدم رغبته في أمور المصالح لمن كان تحت رعايته، بل لمحات الزمان والمكان الني اختارها ابن المقفع تدل على قدرته الفنية وتمكنه

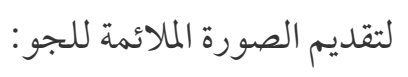

"وذات يوم من أيام الشتاء خرج الثعلب يتمشى فى الغابة ، وكانت الحيو انات الكبيرة قد عرفت بمكانته من الأسد فلم تعد تتعرض له، بل إنها كانت تتحاشاه، وقد زاده ذلك فخرًا

$$
\text { وكبرياء". }
$$

في هذا النص الشتاء رمز للشدة والقسوة التي تعاني الرعايا تحت ظلم الحاكم وعدم عنايته برعيته، فكلمة "يتمشّىى" من باب تفعّل تدل على كبر الحكماء وتفاخرهم على من سو اهم، وتفضّلهم على من يرعاهم، و"يتحاشاه" من باب تفاعل تدل على غضب الرعية على من تو لاهم من الحكام

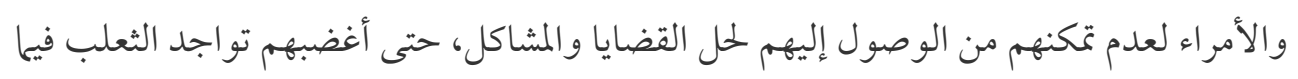

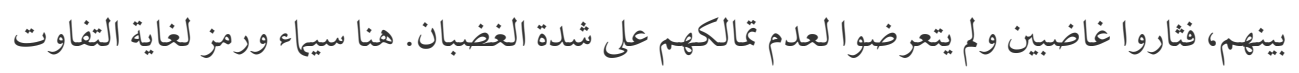
والبعد ما بين الحكام والرعية، الذي يؤدي إلى تفكك الحكومات وتشت الجمع مارما بين الجانبين. 


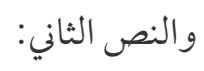

"قال لها الثعلب: أخبريني من علّمك هذا؟ قالت: علّمني مالك الحزين، فتوجّه الثعلب

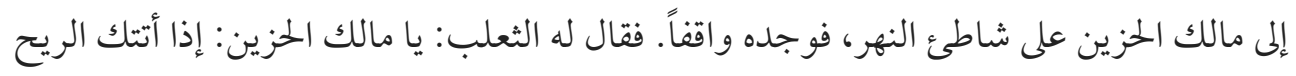

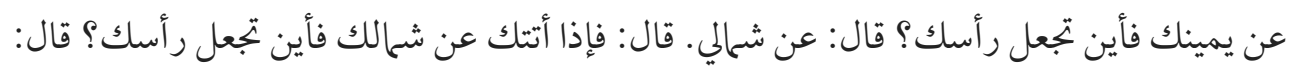
أجعله عن يميني أو خلفي، قال: فإذا أتتك الريح من كل مكان وكل ناحية فأين تجعله؟ قال: أجعله

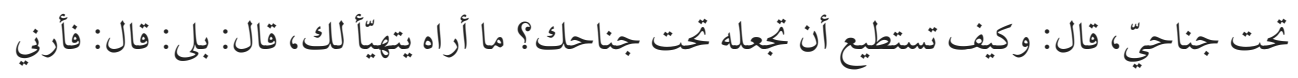

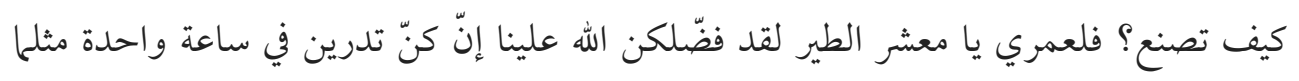
ندري في سنة، وتبلغن ما لا نبلغ، وتدخلن رؤسكن تحت أجنحتكن من البرد والريح، فهنيئاً لكُّنّ

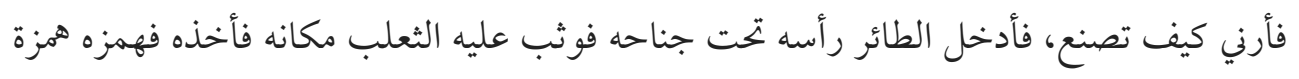

$$
\text { دقت عنقه" (pa). }
$$

في هذا النص أسلوب الاستفهام يحمل رؤيا تأملية ورغبات جامعة متعلقة بالثعلب وما يقاوم مقاومة نفسية للتغلب على مالك الحزين، حيث أسلوب الاستفهام يعطي الكلام حيوية ويزيد من الإقناع والتأثير، كما أنّ فيه إثارة للسامع وجذباً لانتباهه وإشراكا له في التفكير ليصل

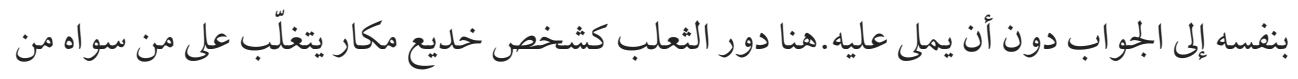

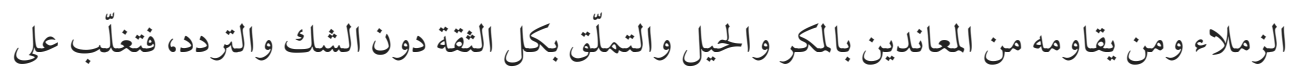
مالك الحزين بالسهولة. فصور الكاتب شخصيته موّظفاً أداة الشرط ( إذا) ، فأداة الشرط (إذاذا)

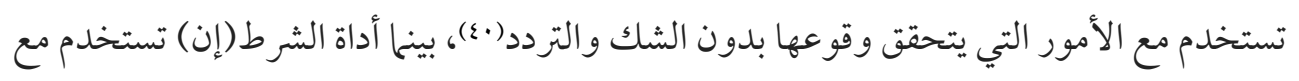
الأمور التي يشك في وقوعها أو يندر وقوعها.

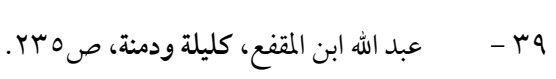

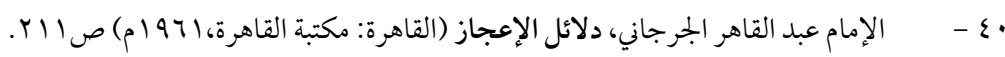




\section{نتائج البحث:}

بعد قراءة القصص الخرافية في كتاب كليلة ودمنة وصلت إلى النتائج التالية:

ا - إنّ القر اءة السيميائية الدلالية في دور الحيوانات في القصة ما هو إلا فتحاً لأبواب أخرى

$$
\text { من القراءات السيميائية لتراثنا الأدبي القديم. }
$$

Y- أما عنو ان الكتاب كلية ودمنة فهو بوابة الولوج لعبور النصوص الأدبية وفتح الذهن

$$
\text { على كثير من التساؤلات. }
$$

ب- فهو نقد هادف على الملوك و أعيان الدولة والسياسة بالرموز والكنايات.

ع - قد قدم الكاتب بالشخصيات الحيوانية صور الحكام والأمراء مستخدما الوسائل الفنية

$$
\text { و اللغوية المتنوعة . }
$$

ه- أمّا فنية الفسلفة والحكمة خلال الأسلوب الأدبي فقد تؤدّي وظيفة تعبيرية وعلامة

$$
\text { أساسية للباحث إلى سبر أغوار النصوص الأدبية . }
$$

7- إنّ الأدب الخرافي ليس للتسيلة والمتعة فقط، بل هو أدب رفيع في ذاته يحتضن العبر

$$
\text { و الدروس القيمة في طيّات الرموز والمجازات لو نحاول للوصول إليها. }
$$

V- فن التخريف يجتاج إلى المزيد من العناية والتوجه للتعبير عن الأسرار والخفايا

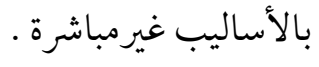




\section{List of References}

Al-Qur'an

1- Abdul Qahir Jurjani, dalāa'īl al-ī jāzz (Cairo: al-maktabä̈ al-qāhirä̈, 1961 AD)

2- Abdullah ibn al-muqaffa, kalīlä̈ wa dimnä̈ (Beirut: dār al-qalam)

3- Adil Fakhuri, tīārāt fĩ al-sīmā' (Beirut: dār al-țalīqä̈ 1990 AD)

4- Adil Fakhuri, 'ilm al-dalāalä̈ 'ind al- arab (dār al-țalì ä̈ ,1985 AH)

5- Ali Waila, min al-ṭuīur wa al-ḥaīwānāt al-barīä̀ fī al-'irāq ( baīrūt: markaz dirāsāt al-'umä̈ al- 'irāqīï, 2010 AD)

6- Ameen Al-Maloof, mu jam al-ḥaīwān ( baīrūt: dār al-rā'īd al'arabī)

7- Dr. Faktoor, ibn al-muqafa 'ādīibu al- aqal (Beirut: Dār ul- Kitab, 1981 AD)

8- Fawad Qandeel, fan kitābä̈ al-qiṣä̈ (Cairo: al-hī' iä̈ al- 'āmä̈ liqaṣūr al-thaqāfä̈, 2002 AD)

9- ḥāshīät al-dasūqī (baīrūt: dār al-surūr)

10- Khateeb Al-Qazweni , al-ị̣̂ạ̣ fî 'ulūm al-balāghä̈ (baīrūt: dār alkitab al-arabi, 2008 AD)

11- Maha Hassan, al-zaman fī al-riwāīä al- 'arabīä̈ ( al-mū'sasä̈ al'arabīä̈ lidirāsāt wālnashr, 2004 AD)

12- Muhammad 'ibn Manzur Al- 'ifrīqī, Lisān ul 'arab (Beirut: Dār Ṣādir, 1990 AD)

13- Muhammad Al-Sarghini, muhạạarāt fī al-sīmuīūlūğīā ( dār althaqāft, 1987 AD)

14- Muhammad Fatuh Ahmad, al-ramz wālramzīä fī al-shi'r almu 'āṣir (Cairo: dār al-ma'ārif, 1987 AD)

15- Muhammad Ghanimi Hilal, al-naqd al-' ādabī al-ḥadīth (Beirut: dār al- 'aūdä̈, 1973 AD)

16- Nasir Abdul Wahid, tārīkh al-fan al-īghrīqī ( baghdād: wazārä̈ alta ' lìm al- 'ālī wa al-baḥth al- 'ilmī, 2010 AD)

17- Research journal Juhainat, Syria, Vol, 64 
18- Research journal, Al-dirasat Al-adabiat wa al-fikriyat, vol, 30, 2017.

19- Roland Barthes, miabādi'i fī 'ilm al-dalāalä̈ ( al-maghrib: dār alqurțabä̈ 1986 AD)

20- Saeed Banghrad, al-sīmīā'T̄āt mafāhīmuhā ūtaṭbīqātuhā (Syria: Dār al-ḥiwār, 2012 AD)

21- Shawqi Abdu Hakeem, al-faūlklwur wāl'āsāṭīr al- arabīä̈ ( dār ibn khaldūn, , 1978 AD)

22- Siza Qasim, binā al-riwāīä̈ (Cairo: maktabä̈ al-' ausrä̈, 2004 AD) 